\title{
Multidisciplinary Integrated Project-based Learning to Improve Critical Thinking Skills and Collaboration
}

\author{
Harli Trisdiono \\ Postgraduate Program, Science Education Department, Sebelas Maret University \\ Surakarta, Central Java, Indonesia \\ Siswandari Siswandari, Nunuk Suryani and Soetarno Joyoatmojo \\ Faculty of Teacher Training and Education Sebelas Maret University, \\ Surakarta, Central Java, Indonesia
}

\begin{abstract}
The purpose of this study was to look at the effectiveness of multidisciplinary integrated project-based learning models in enhancing critical thinking and collaboration among elementary school students. The study used a quasi-experimental research technique with three subjects as experimental subjects and 65 students, and three subjects as control subjects and 65 students. The results of the study indicate that multi-disciplinary integrated project-based learning can improve critical thinking skills and student collaboration. This is evidenced by the t-test. $\mathrm{T}$ table obtained at the significance level of $5 \%$ is 2006 . So the value of $t$ count $>t$ table $(30,570>2,006)$ and the significance value is less than 0.05 $(p=0,000<0,05)$. It can be concluded that critical thinking skills and collaboration differ significantly in the experimental class and the control class.
\end{abstract}

Keywords: project-based learning, multidisciplinary, critical thinking, collaboration.

\section{Introduction}

The quality of education is determined by input factors and the learning process. Input includes students, teachers, infrastructure, environment, and curriculum (Uysal, 2015). The process includes theories, concepts, strategies, models, methods, and learning environments that are applied to teaching and learning activities. The process occurs in schools (OECD, 2005, p. 12). Each factor has a very diverse influence. The quality of teachers in mastering the material, understanding of theories, models, strategies, methods of learning, and feedback to students (Gage, et al., 2017) determine the facilitation process carried out to achieve certain competencies. The teacher must understand how students learn 
and how to facilitate students learning (Furner \& Kumar, 2007). The role of the teacher turns into a facilitator ( $\mathrm{Li} \&$ Chen, 2018). As a facilitator the teacher is required to be able to understand the facilitating techniques and characteristics of each student so that they can facilitate more individually. Learning that prepares students for the challenges of the 21st century is done by teachers who understand and know what to do (North Carolina State Board of Education, 2007), namely: 1) Leadership is shared with all school stakeholders, so that the vision and goals of the school are shared ; 2) Teachers make learning content interesting, relevant, and meaningful for students' lives; 3) Teachers with students build learning competencies that incorporate critical thinking skills, problem solving, and information and communication technology literacy (ICT); 4) The teacher facilitates learning by encouraging all students to be able to find ways to learn, innovate, collaborate, and convey ideas; 5) health, financial literacy, awareness as citizens, global society, and environmental awareness become one of the learning materials; 6) linking the relevance of learning with the community; 7) Teachers reflect on learning, assessment, and conveying feedback to students; 8) The teacher encourages students to lifelong learning.

The learning process of the 21st century changes from teacher-centered to student-centered. 21st century education prepares students in the knowledge of content (mastery of subjects) and technological skills, becoming global citizens (global citizenship) and future success (Smaldino, 2011). According to Djohar (2006) education in Indonesia has not fully answered the process changes, because of the negative characteristics that occur in education in Indonesia, namely: 1) textual, studies conducted in the education process are studies of the work of others, not relying on their own actions and results own work; 2) product oriented, by ignoring the process, which results in our children not having the potential for individual learning, they rely on the end result; 3) final evaluation, as a result of our educational orientation to the product, the evaluation is focused on the product. Process evaluation in the form of a portfolio is never used as a measure of student progress; 4) IQ-oriented, by only paying attention to students from innate intelligence never touches the intelligence that can be grown through the development of creativity (CQ), EQ, and SQ. Even more towards AQ; 5) centric for school, meaning that our education only has the meaning to continue school, does not have the meaning to meet life in the future. Therefore, its orientation is backward, not anticipatoryforward perspective.

The importance of the quality of education in entering the 21st century era is highlighted by Soedijarto (1997). Schools in preparing students to enter the 21st century must be able to socialize various values and attitudes and learning abilities, this is one of the characteristics of quality education. The characteristics of quality education will produce people who: 1) have faith and devotion to the Almighty God and noble character; 2) have knowledge and skills; 3) physically and mentally healthy; 3) steady and independent personality; 4) have a sense of social and national responsibility (Soedijarto, 1997). According to Savin-Baden and Major (2004) students must learn to: 1) communicate effectively verbally and nonverbally; 2) understand and be able to do qualitative and quantitative analysis to solve problems; 3) conduct interpretation and evaluation of information from various sources; 4 ) understand and be able to work in complex 
systems and in different groups; 5) show intellectual ability and and be able to adapt to change; 6) transform information into knowledge and and use it to make decisions and actions. These six things are the provisions needed to face the increasingly complex challenges of life.

The six things that must be mastered by students according to SavinBaden and Major (2004) cannot be done with conventional, monotonous processes, and by relying on a single method, model, and strategy. According to Soedijarto (1997) a quality learning process is a learning process that meets the criteria of elements of relevance, namely: 1) the relevance of epistemology; 2) psychological relevance; 3) social relevance; and 4) relevance to the values contained. In order for learning to be able to fulfill that relevance, learning must be able to provide a significant learning experience. A significant learning experience (significant learning experiences) has an impact on student competence (Fink, 2003) on values: 1) improving individual life, such as enjoying art and music, developing meaningful life; 2) increasing contributions in social life such as in the family, environment, country, religion, group, world; 3) preparing individuals to enter the workforce such as developing the knowledge, skills and attitudes needed to increase effectiveness in the professional world.

The characteristics of the significant learning experiences students are involved in the process. This means that students become planners, implementers and evaluators of education. The education process also has high energy. Classes are able to provide support for students to follow the education process. Education provides significant and lasting changes in the results, impact, and outcomes side, which results in significant changes in students, continuous changes after learning is completed and after students graduate. Education also provides value in life, which is learned to have high potential to be a value in life, by improving personal life, preparing students to participate in various communities.

Suyanto (2013) warns that curriculum and learning processes need to provide sufficient space so that students can make observations, analyses, hypotheses, syntheses, and find solutions to challenges faced in the learning process. The learning process, to ensure competency achievement needs to be followed by a good assessment process. Assessment is carried out authentically on learning processes and results. From this assessment process, the quality of education can be improved. The quality of planning, implementation and assessment determines the success of education.

The application of learning methods at the primary / secondary school level is carried out through learning with thematic-integrated approaches from Class I to Class VI. Religious Education and Characteristics subjects are excluded (Permendikbud Number 57 of 2014). The learning process is carried out by combining subjects with themes as organizers of teaching materials, attitudes to be developed, and skills that are trained. Integrated learning is learning that integrates various competencies in the learning process (Alberta Education, 2007, p. 2; Gnanakan, 2007, p. 18; Fogarty, 1991; Loepp, 1999; Drake \& Burns, 2004; Intel Education, 2008). The pattern of integrated learning approaches in general is intra-disciplinary, inter-disciplinary, multi-disciplinary, and transdisciplinary integration. 
Intra-disciplinary integrated learning is done by integrating the dimensions of attitudes, knowledge, and skills into one whole unit in each subject. Inter-disciplinary integration is done by combining the basic competencies of some subjects so that they are related to one another, so that they can strengthen each other, avoid overlapping, and maintain learning harmony. Multi-disciplinary integration is carried out without combining the basic competencies of each subject so that each subject still has its own basic competencies. Trans-disciplinary integration is done by linking the various existing subjects with the problems found around them so that learning becomes contextual.

The results of preliminary research conducted on 52 teachers who have implemented single-discipline project-based learning, the teacher believes that the project-based learning model is able to improving students' skills. When asked whether the teacher had implemented multidisciplinary project-based learning, most of the teachers answered yes. This suggests that it is important to do research on multidisciplinary integrated project-based learning in relation to critical thinking skills and student collaboration.

\section{Theoretical Framework}

Project-based learning is designed to facilitate students in getting to know the real world (Cervantes, Hemmer, \& Kouzekanani, 2015), through increasing learning activities (Cakiroglu, 2015). Learning activities are carried out by involving students in managing learning (Ilter, 2014). Students learn by using the knowledge they already have (Jacques, 2017). Thus when students use a project-based learning model, creativity and critical thinking skills increase (Anazifa \& Djukri, 2017; Desinta, Bukit, \& Ginting, 2017; Rachmawati, et.al., 2018), so that they can improve level thinking skills high (Pinho-Lopes \& Macedo, 2014: 20-27). Increased students' critical thinking skills because during the learning process students are directly involved. Students have experience discovering facts through activities seeking information and combining various knowledge from various kinds of subjects (Li, 2018). Florea \& Hurjui (2015) found that learning that develops students' critical thinking skills must be developed in the learning process that accommodates high-level thinking skills, taking into account the quality of questions, the quality of thinking, and the quality of response.

According to Asan \& Haliloglu (2005) project-based learning can improve the ability to work in groups, so as to improve cooperation skills. On the other hand it can also increase learning motivation (Anazifa \& Djukri, 2017). Encourage students to help develop questions and find solutions (Anazifa \& Djukri, 2017). Responsible for learning, independence and discipline (Bell. 2010) and improving problem-solving skills and high-level thinking (Pinho-Lopes \& Macedo, 2014). This happens because project-based learning is able to increase interaction with learning (Pereira, Barreto, \& Pazeti, 2017; Lawe, 2018), increase student motivation (Chiang \& Lee, 2016; Ilter, 2014), improve learning effectiveness (Asan \& Haliloglu, 2005). Critical thinking skills and increased collaboration increase opportunities to apply practical theory and knowledge 
(Asan \& Haliloglu, 2005). Thus the process that occurs because project-based learning is learning based on student activities.

As student activity-based learning project-based learning will be meaningful if it meets two criteria, namely: 1) students feel the meaning personally, so they want to carry out the project well; 2) fulfill educational goals (Larmer \& Mergendoller, 2010). Personal implementation is important because project-based learning requires more effort than conventional learning, when students feel personal meaningfulness is expected to give a strong impetus to implement PBP. Some conditions that can support personal meaningfulness according to (Patton, 2012; Larmer \& Mergendoller, 2010) can be achieved with PBP characters, namely public exhibition or presentation, producing products, the need to know, choices and opinions of students; investigation; feedback; revision; and critique. Publication activities are activities carried out by students to convey their learning outcomes, which can be a particular product to the community. After completing learning, students critique or evaluate the process and learning outcomes so students can interpret it personally.

Miller (2018) states that project-based learning has an impact on increasing the learning process into meaningful learning. Students have the opportunity to make improvements (Mutakinati, Anwari, \& Yoshisuke, 2018: 54-65), students act as teachers (Goodman, 2010: 1-8). Learning ends with making a project (Bilgin, Kemal, \& Ay; 2015). Project-based learning also gives students the opportunity to experience learning in order to actively develop knowledge and enhance experience (Gerogiannis \& Fitsilis, 2005). Project-based learning is a method that emphasizes contextualization, real experiences needed by students to support learning and build full meaningfulness. PBP is also challenging and motivating to students. Besides, it develops critical, analytical thinking skills and improves high-level thinking skills. Project-based learning requires collaboration, communication, problem solving and self-directed learning (Capraro \& Slough, 2009). Project-based learning allows students to construct their knowledge based on the knowledge they already have (Bell, 2010); provides significant benefits (Hernández-Ramos \& Paz, 2009); have a positive impact on the achievement of teaching material competencies (Jacques, 2017; Cervantes, Hemmer, \& Kouzekanani, 2015)

Project-based learning is able to improve critical thinking skills and problem solving (Mergendoller, et al., 2006); improve collaborative skills and resolve conflicts (Chan Lin, 2008); improve social skills; improve management, cooperation, and accuracy skills when working in groups. The application of project-based learning according to Thomas (2000) must meet five criteria, namely: (a) the project is central, not part of the curriculum; (b) projects focus on how students find problems and concepts from the material being studied, through questions that are made; (c) the project involves students in constructive research; (d) the project encourages students to reach a significant level; and (e) the project must be realistic, not what the school wants. Project as a center means placing the project as the main activity in achieving competencies that focus on real problems in life. Projects also involve students in realistic research activities to achieve the desired competencies.

Critical thinking is a process that occurs because of an understanding of the various information that is integrated (Lunenburg, 2011) through learning 
skills (Peter, 2012). Because critical thinking occurs through learning skills, it requires a thinking process that requires the ability of analysis, synthesis, and evaluation. This ability will show beliefs and actions (Scriven \& Paul, 2007; Marcut, 2005). According to Paul \& Elder (2008) critical thinking is the art of analyzing and evaluating thoughts carried out with the intention of developing that thought. Cottrell (2005) defines critical thinking as a complex process that involves various attitudes and skills. Critical thinking means applying logic systematically and questioning every demand or belief; think carefully and strictly (Novella, 2012), make judgments about the truth and value of statements and ideas (Stancato, 2000). According to Reed and Kromley (2001), critical thinking is the ability and tendency to analyze complex issues and situations, recognize and evaluate assumptions and alternative points of view according to acceptable criteria, make conclusions, draw reasonable conclusions based on accurate information, make interdisciplinary connections, and transfer insights to new contexts. Critical thinking defines as a cognitive skill that determines how well a person collects, processes, and uses information to identify the best way to achieve goals or navigate complex situations. Based on these definitions, it can be concluded that critical thinking is a systematic, complex intellectual process, involving various attitudes and skills, accompanied by a process of analyzing and evaluating within the framework of making improvements.

Critical thinking as an intellectual process involves the activities of attitudes, knowledge, and skills. The main activities in critical thinking are analysis, evaluation, and argumentation (Butterworth \& Thwaites, 2013; Novella, 2012; Astleitner, 2001). Critical thinking has various elements. Paul and Elder (2004) say that critical thinking means: every thought has a purpose; looking for new things; find solutions; use data; consider various things, always based on information; utilize the available evidence; and based on concepts and ideas that result from a learning process; contain conclusions and give meaning; and has implications and consequences. Understanding the main activities and critical thinking elements provides conclusions that critical thinking is systematic steps in seeking information, processing, analyzing, and synthesizing that information so that it becomes a conclusion or benefit according to the objectives set. The process involves a variety of intact viewpoints as a component of critical thinking.

The component of critical thinking involves high-level thinking (Hemming, 2000; Duplass \& Ziedler, 2002; Wong, 2007) according to Bloom's learning taxonomy which was revised by Anderson (2001) and thought scientifically. Anderson (2001) divides the taxonomy of learning into the knowledge dimension and dimensions of cognitive processes. The knowledge dimension consists of factual knowledge, conceptual knowledge, procedural knowledge, and metacognitive knowledge. The dimensions of the cognitive process consist of remembering, understanding, applying, analyzing, evaluating, and creating. As cognitive skills, critical thinking reflects the ability of interpretation, analysis, evaluation, inference, explanation, and self-regulation (Facione, 2011). According to Yildirim and Özkahraman (2011) the process of critical thinking is to find, obtain, evaluate, analyze, synthesize, and conceptualize information. The results of thinking activities are used to solve problems. 
Collaboration is defined as social construction to build relationships with members to achieve successful goals (Volkov \& Volkov, 2007; Salas et al., 2005, Hughes \& Jones, 2011) thus collaboration involves working together in teams. Cooperation skills are very important for students because cooperation can improve adaptability, productivity, and creativity (Salas, et al. 2005), improve communication, resolution and negotiation skills (Crebert, et al. 2011). Collaboration is done by building relationships and working with others using core skills and habits. Team members work cooperatively, contributing with ideas, advice and effort. Communication needs in developing teams are accompanied by responsibilities that are able to increase respect for differences of opinion, habits, and individual preferences. In the end, each team member is able to participate in decision making.

The effectiveness of team work results from appropriate membership, size and resources; good leadership, assignments and attention to commitment to team building, understanding and identifying goals with each other; development of team goals - shared vision, coordination and division of tasks that are evenly distributed to all team members, so that the team has high performance.

Holmes (2013) states that there are ten high-performance team characters, namely: 1) Developing goals and planning, 2) developing communication; 3) building and maintaining positive relationships; 4) solving problems and making time-based decisions; 5) conflict management; 6) facilitating productivity; 7) clear roles for each member; 8) operating in a productive manner; 9) effective team leadership; 10) providing opportunities for developing team members. These characters need to be shared by each team member. Lingard (2010) identifies collaborative attributes, namely: attending team meetings; arrive on time; donating new ideas; express opinions; communicate clearly; sharing knowledge; mutual support; understand the opinions of team members; help each other; care for members who need help; complete responsibility on time; complete tasks with good quality; various with team members; committed to team goals; show ability for team success.

\section{Method}

The method section describes the research methods used including research design, research subjects, and data analysis.

\section{Research Design}

The research conducted is experimental research as part of a series of research and development. At this stage of research is a test of the effectiveness of development products tested through experimental research. Experimental research conducted was quasi-experimental research.

\section{Research subjects}

The research subjects were divided into two groups, namely the experimental group and the control group. The experimental group consisted of three teachers in three schools with a total of 65 students. The control group consisted of three teachers from three schools with 65 students. The subjects were of a school in the Special Region of Yogyakarta. 


\section{Data analysis}

Data was obtained using pretest and posttest techniques. Pretest is an observation made to students before the experiment was conducted. Posttest is observations made at the time and during treatment. Data were taken using the following instruments:

Table 1. Observation Instruments Critical Thinking Skills

\begin{tabular}{ll}
\hline \multicolumn{1}{c}{ Aspects } & \multicolumn{1}{c}{ Symptoms } \\
\hline $\begin{array}{l}\text { 1. Search, process and } \\
\text { analyze information }\end{array}$ & $\begin{array}{l}\text { a. Use various sources of information } \\
\text { b. Make information notes and make mind maps } \\
\text { c. Distinguish information that is in accordance } \\
\text { with what is not appropriate }\end{array}$ \\
\hline 2. Answering questions & $\begin{array}{l}\text { a. Answering fundamental questions based on } \\
\text { logical arguments } \\
\text { b. Answering learning questions and linking them } \\
\text { with various perspectives }\end{array}$ \\
\hline 3. Make questions & $\begin{array}{l}\text { a. Make questions that have broad answers and } \\
\text { require comprehensive thinking, and require } \\
\text { argumentation in answering. }\end{array}$ \\
& $\begin{array}{l}\text { b. Make questions that can provoke curiosity } \\
\text { 4. Solve problems }\end{array}$ \\
$\begin{array}{l}\text { a. Use information as a material for decision } \\
\text { making Propose alternative methods to solve problems } \\
\text { c. Describe the differences and similarities of } \\
\text { problems }\end{array}$
\end{tabular}

For collaboration skills the data were taken using the following instruments:

Table 2. Observation Instruments Critical Thinking Skills

\begin{tabular}{|c|c|}
\hline Aspects & Symptoms \\
\hline $\begin{array}{l}\text { 1. Give contributions to } \\
\text { the group }\end{array}$ & $\begin{array}{l}\text { a. Convey ideas related to the concept and } \\
\text { operational implementation of activities } \\
\text { b. Provide support to the team in preparing, } \\
\text { implementing and evaluating work } \\
\text { c. Participate in decision making by providing } \\
\text { additional insight }\end{array}$ \\
\hline 2. Communicative & $\begin{array}{l}\text { a. Appreciate the opinions of others with an } \\
\text { enthusiastic attitude to pay attention to others } \\
\text { when expressing opinions } \\
\text { b. Responding to the opinions of others in good } \\
\text { language } \\
\text { c. Conveying opinions politely }\end{array}$ \\
\hline 3. Responsibility & $\begin{array}{l}\text { a. Accept regulations that have been agreed upon } \\
\text { or socialized together } \\
\text { b. Complete the task that is part of it } \\
\text { c. Care for the success of team activities }\end{array}$ \\
\hline
\end{tabular}


Data obtained from observations were then compared between the control class and the experimental class. The test is carried out by t-test.

\section{Results}

Research on the development of multidisciplinary integrated project-based learning models, shows the results that models developed are effective for enhancing critical thinking skills and collaboration. This is indicated by a test of the experimental class and the control class. The results of the study are shown in each section. Tests in the experimental class and control class were conducted to see whether there was an increase in critical thinking skills and collaboration in each class. Comparison test of posttest results between experimental class and control class to find out the differences that occur because of the use of multidisciplinary integrated project-based learning models.

Test the Pretest Paired Sample T-Test and Postest Experiment Class

Test paired sample pretest and posttest t-test experimental class aims to determine whether there is an increase in score. The conclusion of the study is stated to be significant if $t$ count $>t$ table at a significant level of $5 \%$ and the value of $p<0.05$. The summary of the paired sample t-test results of the experimental class is shown in the following table:

Table 3. Paired Sample T-Test Pretest and Post-Test Class

\begin{tabular}{|c|c|c|c|c|c|}
\hline Parameter & Ekp & Mean & T-count & T-table & $\mathrm{P}$ \\
\hline $\begin{array}{l}\text { Critical Thinking } \\
\text { Skills }\end{array}$ & $\begin{array}{l}\text { pretest } \\
\text { postets }\end{array}$ & $\begin{array}{l}72.4154 \\
89.4769\end{array}$ & 20.760 & 2.006 & 0.000 \\
\hline Cooperation Skills & $\begin{array}{l}\text { Pretes } \\
\text { postest }\end{array}$ & $\begin{array}{l}75.7077 \\
89.2651\end{array}$ & 14.619 & 2.006 & 0.000 \\
\hline
\end{tabular}

The average value of the critical thinking skills pre-test of the experimental class students was 72.41 and the average post-test score was 89.48 so that it increased by 17.66. Also, obtained $t$ count $>t$ table at a significance level of $5 \%$ $(20,760>2,006)$ and has a value of $p<0.05$ which means that there is a significant increase in the critical thinking skills score of the experimental group students.

The average score of the experimental class cooperation student pre-test skills was 75.71 and the average post-test score was 89.76 so that it increased by 13.56. Also obtained $t$ count $>t$ table at a significance level of $5 \%(14,619>2,006)$ and has a value of $p<0.05$ which means that there is a significant increase in the student group collaboration skills proficiency score.

\section{Test Paired Sample Tets Test and Postest Control Class}

Test paired sample pretest and posttest t-test of the control class aims to determine whether there is an increase in score. The conclusion of the study is stated to be significant if $t$ count $>t$ table at a significant level of $5 \%$ and the value of $p<0.05$. As for the summary of the paired sample t-test results of the experimental class are shown in the following table: 
Table 4. Paired Sample T-Test Pretest and Post-Test Class Control

\begin{tabular}{|c|c|c|c|c|c|}
\hline Parameter & Ekp & Mean & T-count & T-table & $\mathrm{P}$ \\
\hline $\begin{array}{l}\text { Critical Thinking } \\
\text { Skills }\end{array}$ & $\begin{array}{l}\text { pretest } \\
\text { postets }\end{array}$ & $\begin{array}{l}66.6154 \\
77.0769\end{array}$ & 8.948 & 2.006 & 0.000 \\
\hline Cooperation Skills & $\begin{array}{l}\text { Pretes } \\
\text { postest }\end{array}$ & $\begin{array}{l}66.0000 \\
73.8462\end{array}$ & 10.190 & 2.006 & 0.000 \\
\hline
\end{tabular}

The average value of the pre-test of critical thinking skills of the control class students was 66.61 and the average post-test score was 77.08 so that it increased by 10.46. Also, obtained $t$ count $>t$ table at a significance level of $5 \%$ $(20,760>2,006)$ and has a value of $p<0.05$ which means it can be concluded that there is a significant increase in the critical thinking skills score of the control group students.

The average value of the control class cooperation skill pre-test is 66.00 and the post-test score is 73.85 so that it increases by 7.85 . Also, obtained $t$ count $>t$ table at a significance level of $5 \%(14,619>2,006)$ and has a value of $p<0.05$ which means that there is a significant increase in the skill score of the cooperation control group students.

\section{Test Paired Sample T-Test Posttest in the Experimental and Posttest Control Class}

Test paired sample t-test on the experimental class posttest and posttest control class aims to determine whether there are significant differences in the posttest values in the experimental class and the control class. The conclusion of the study is stated to be significant if $t$ count $>t$ table at a significant level of $5 \%$ and the value of $p<0.05$. As for the summary of the paired sample t-test results of the experimental class are shown in the following table:

Tabel 5. Paired Sample T-Test Postest Class Experiments and Postest Control Classes

\begin{tabular}{|c|c|c|c|c|c|}
\hline Parameter & Kelas & Rata-rata & $\mathrm{T}$-count & T-table & $\mathrm{P}$ \\
\hline \multirow{2}{*}{$\begin{array}{l}\text { Critical } \\
\text { Thinking Skills }\end{array}$} & Postest & 89.4769 & \multirow{2}{*}{27.121} & \multirow{2}{*}{2.006} & \multirow[b]{2}{*}{0.000} \\
\hline & $\begin{array}{l}\text { Eksperimen } \\
\text { Posttest Control }\end{array}$ & & & & \\
\hline \multirow{2}{*}{$\begin{array}{l}\text { Cooperation } \\
\text { Skills }\end{array}$} & Postest & & \multirow[b]{2}{*}{30.570} & \multirow[b]{2}{*}{2.006} & \multirow[b]{2}{*}{0.000} \\
\hline & Eksperimen & & & & \\
\hline
\end{tabular}

The results of paired samples t-test post-test critical thinking skills are known to average the results of experimental class critical thinking skills of 89.48 and the average results of the thinking skills of the control class is 77.08. Thus, it can be concluded that the average results of experimental class critical thinking skills 12.40 greater than the control class. From the table, it is known that t count is 27,121 with a significance of 0,000 . $\mathrm{T}$ table obtained at the significance level of $5 \%$ is 2006 . Hence, the value of $t$ count $>t$ table $(27.121>2,006)$ and the significance value is less than $0.05(p=0,000<0,05)$. It can be concluded that there are differences in the scores of the results of students' critical thinking skills significantly in the experimental class and the control class. 
Based on the paired samples post-test collaboration skills t-test it is known that the average results of the experimental class cooperation skills are 89.26 and the average results of the control class cooperation skills are 73.85. As a result, the experimental class critical thinking skills results 15.41 larger compared to the control class. From table 5, it is known that $\mathrm{t}$ count is 30,570 with a significance of 0,000 . $T$ table obtained at the significance level of $5 \%$ is 2006 . Therefore, the value of $t$ count $>t$ table $(30,570>2,006)$ and the significance value is less than $0.05(\mathrm{p}=0,000<0,05)$. It can be concluded that there are differences in the scores of the results of students' critical thinking skills significantly in the experimental class and the control class.

\section{Discussion}

Based on the results of the study, multidisciplinary integrated project based learning can improve critical thinking skills and student collaboration. These results reinforce the results of research that project-based learning enhances critical thinking skills (Anazifa \& Djukri, 2017; Desinta, Bukit, \& Ginting, 2017), so that it is also able to improve higher-order thinking skills (Pinho-Lopes \& Macedo, 2014). Florea \& Hurjui (2015) found that learning that develops students' critical thinking skills must be developed in the learning process that accommodates high-level thinking skills, taking into account the quality of questions, the quality of thinking, and the quality of response.

Students' critical thinking skills can be improved through multidisciplinary integrated project-based learning because when students do the learning process, students learn how to think. These findings are in accordance with the findings of Asan \& Haliloglu (2005) which states that project-based learning can improve the ability to work in groups. The findings of this study are in accordance with the findings of Asan and Haliloglu (2005) that PBL was able to improve collaboration skills. However, it can also increase learning motivation (Anazifa \& Djukri, 2017). Encourage students to help develop questions and find solutions (Anazifa \& Djukri, 2017). Responsible for learning, independence and discipline (Bell. 2010) and improving problemsolving skills and high-level thinking (Pinho-Lopes \& Macedo, 2014).

\section{Conclusion}

Multidisciplinary integrated project-based learning can improve critical thinking skills and collaboration with elementary school students.

\section{References}

Alberta_Education. (2007). Primary programs framework - curriculum integration : making caonnections. Alberta: Alberta Education.

Anazifa, R. D., \& Djukri. (2017). Project-Based Learning and Problem-Based Learning: Are They effective to improve Student's thingking skills? Jurnal Pendidikan IPA Indonesia, 6(2), 346-355 DOI: 10.15294/jpii.v6i2.11100.

Anderson, L. W., \& Krathwohl, D. R. (2001). A Taxonomy for learning, teaching, and assesing. a revision of Bloom's taxonomy of education objectives. New York: Addison Wesley Longman.

Asan , A., \& Haliloglu, Z. (2005). mplementing project based learning in computer classroom . The Turkish Online Journal of Educational Technology. 4(3), 68-81. 
Astleitner, H. (2001). Teaching critical thinking online. Journal of Instructional Psychology, 29(2), 53-76.

Barron, B., \& Darling-Hammond, L. (2008). Teaching for Meaningful Learning: A Review of Research on Inquiry-Based and Cooperative Learning. San Francisco: John Wiley \& Sons Inc.

Bell, S. (2010). Project-based learning for the 21st century: Skills for the future. The Clearing House, 83, 39-43. https:// doi.org/10.1080/00098650903505415 .

Bilgin, I., Karakuyu, Y., \& Ay, Y. (2015). The Effects of Project Based Learning on Undergraduate Students' Achievement and Self Efficacy Beliefs Towards Science Teaching. Eurasia Journal of Mathematics, Science \& Technology Education, 2015, 11(3), 469-477.

Boaler, J. (1997). Experiencing school mathematics: Teaching styles, sex, and settings. Buckingham: UK: Open University Press.

Boondee, V., Kidrakarn, P., \& Sa-Ngiamvibool, W. (2011). Learning and Teaching Model using Project-Based Learning (PBL) on the Web to Promote Cooperative Learning. European Journal of Social Sciences - Volume 21, Number 3, 498 - 506.

Butterworth, J., \& Thwaistes, G. (2013). Thingkins skills critical thingking and problem solving. Cambridge: Cambridge University Press.

C. L. Chiang, \& H. Lee. (2016). The Effect of Project-Based Learning on Learning Motivation and Problem-Solving Ability of Vocational High School Students. International Journal of Information and Education Technology, 6(9), 709-712 DOI: 10.7763/IJIET.2016.V6.779.

Cakiroglu, U. (2014). Enriching Project-Based Learning Environments with Virtual Manipulatives: A Comparative Study. Eurasian Journal of Educational Research(55), 201-222 http://dx.doi.org/ 10.14689/ejer.2014.55.12.

Capraro, R. M., \& Capraro, M. M. (2002). Myers-Briggs Type Indicator Score Reliability Across: Studies a Meta-Analytic Reliability Generalization Study. Educational and $\begin{array}{lllll}\text { Psychological Measurement } & 62, & 549 & - & 602 .\end{array}$ https://doi.org/10.1177/0013164402062004004 .

Capraro, R. M., \& Slough, S. W. (2009). Project-based learning: An integrated science, technology engineering, and mathematics (STEM) approach. Rotterdam: Sense Publishers.

Cervantes, B., Hemmer, L., \& Kouzekanani, K. (2015). The impact of project-based learning on minority student achievement: Implications for school redesign . NCPEA Education Leadership Review of Doctoral Research, 2(2), 50-66.

ChanLin, L.-J. (2008). Technology integration applied to projrct-based learning in science Vol. 45, No. 1. Innovation in Education and Teaching International, 55-65. https://doi.org/10.1080/14703290701757450 .

Cottrell, S. (2005). Critical Thinking Skills : Developing effective analysis and argument. New York: Palcrave Macmillan.

Desinta, F., Bukit, N., \& Ginting, E. M. (2017). The Effect ofProject Based Learning(PjBL) andSelf Regulated Learningtoward Students' Critical Thinking Skill in Senior High School. IOSR Journal of Research \& Method in Education (IOSR-JRME), 7(4 Ver. II), 59-63 DOI: 10.9790/7388-0704025963.

Drake, S. M., \& Burns, R. C. (2004). Meeting standards through integrated curriculum. Alexandria: Association for Supervision and Curriculum Development (ASCD).

Duplass, J. A., \& Ziedler, D. L. (2002). Critical thinking and logical argument. Social Education, 66(5), 10-14.

Facione, P. A. (2011). Critical Thinking: What It Is and Why It Counts. Millbrae: Measured Reasons and The California Academic Press.

Fink, L. (2003). Creating significant learning experiences: An Integrated Approach to Designing College Courses. San Francisco: Jossey-Bass Publishers,. 
Florea, N. M., \& Hurjui, E. (2015). Critical thinking in elementary school children. Procedia - Social and Behavioral Sciences, 180, 565 - 572. https://doi.org/10.1016/j.sbspro.2015.02.161 .

Fogarty, R. (1991). Ten ways to integrated curriculum. Educational Leadership, Oktober 1991, 61-65.

Furner, J. M., \& Kumar, D. D. (2007). The Mathematics and Science Integration Argument: A Stand for Teacher Education. Eurasia Journal of Mathematics, Science $\mathcal{E}$ Technology Education, 2007, 3(3), 185-189. https://doi.org/10.12973/ejmste/75397 .

Gage, N. A., Scott, T., Hirn, R., \& MacSuga-Gage, A. S. (2017). The Relationship Between Teachers' Implementation of Classroom Management Practices and Student Behavior in Elementary School. Behavioral Disorders, 302-315. https://doi.org/10.1177/0198742917714809 .

Gerogiannis, V., \& Fitsilis, P. (2005/2006). A Project-Based Learning Approach for Teaching ERP Concepts. International Journal of Learning 12, http://www.Learning-Journal.com,.

Gnanakan, K. (2007). Learning in an integrated environment. Bangalore: Theological Book Trust.

Goodman, B. (2010). Project-Based Learning. Educational Psychology, 1-8.

Grant, M. (2009). Understanding projects in project-based learning: A student's perspective. Annual Meeting of the American Educational Research Association. San Diego, CA.

Hemming, H. E. (2000). Encouraging critical thinking: "But...what does that. Journal of Education, 35(2), 173.

Hernández-Ramos, P., \& Paz, S. D. (2009). Learning History in Middle School by Designing Multimedia in a Project-Based Learning Experience. Journal of Research on Technology in Education 42(2), 151-173. https://doi.org/10.1080/15391523.2009.10782545.

Holmes, T. A. (n.d.). http://www.doctorholmes.net/Ten Characteristics of a High Performance Work Team.pdf.

Hughes, R. L., \& Jones, S. K. (2011). Developing and assesing college student teamwork skills. New Direction for Institutional R\%esearch No. 149 Spring 2011, 53 - 64 DOI10.100/ir.380.

Ilter, I. (2014). A Study on the efficacy of project-based learning approach on Social Studies Education: Conceptual achievement and academic motivation. Academic Journals Educational Research and Review, 9(15), 487-497 DOI: 10.5897/ERR2014.1777.

Intel_Education. (2008). Program Pelatihan Intel Essentials Course. Jakarta: Intel Education Indonesia.

Jacques, L. A. (2017). What does Project-based Learning (PBL) Look like in the Mathematics Classroom? . American Journal of Educational Research, 5(4), 428-433. DOI:10.12691/education-5-4-11 .

Jonassen, D. H., Howland, J., Moore, J., \& Marra. (2003). Learning to solve problems with technology. A constructivist perspective (2nd ed.). Upper Saddle River, NJ: Merrill Prentice Hall.

Klein, J. I., Taveras, S., King, ,. S., Commitante, A., Curtis-Bey, L., \& Stripling, B. (2009). Project-Based Learning: Inspiring Middle School Students to Engage in Deep and Active Learning Division of Teaching and Learning Office of Curriculum, Standards, and Academic Engagement. New York: NYC Department of Education.

Kubiatko, M., \& Vaculová, I. (2011). Project-based learning: characteristic and the experiences with application in the science subjects. Energy Education Science and Technology Part B: Social and Educational Studies, 3(1), 65-74. 
Larmer, J., \& Mergendoller, J. R. (2010). 7 essensial for project based learning. Educational Leadership, Volume 68, Number 1,September 2010.

Lawe, Y. U. (2018). Pengaruh model pembelajaran berbasis proyek berbantuan lembar kerja siswa terhadap hasil belajar IPA siswa SD. Journal of Education Technology. 2 (1), 26-34.

Li , H., \& Chen, Y. (2018). Conceptions on PBL Facilitator's Role: A Perspective of Chinese Teacher . International Journal of Learning, Teaching and Educational Research 17(9), 18-33.

Li, H. (2018). Facilitating Learning through PBL in a Chinese Context: Students' Learning Outcomes and Attitudes. International Journal of Learning, Teaching and Educational Research 17(7), 80-93.

Lingard, R. W. (2010). Teaching and assessing teamwork skills in enginering and computer science. Systemics, Cybernetics and Informtics 8(1), 34 - 37.

Loepp, F. L. (1999, Summer/Fall). Models of Curriculum Integration. The Journal of Technology Studies, XXV (2), 21-25.

Lunenburg, F. C. (2011). Critical Thinking and Constructivism Techniques for Improving Student Achievement. National Forum Of Teacher Education Journal 21(3), 1-9.

Marcut, I. (2005). Critical thinking - applied to the methodology of teaching mathematics. Educat, ia Matematic a Vol. 1, Nr. 1, 57 - 66.

Markam, T., Larmer, J., \& Ravitz, J. (2003). Project based learning handbook. . Novato, CA: Wilsted \& Taylor Publishing Services.

Mergendoller, J. R., Maxwell, N. L., \& Bellisimo. (2006). The effectiveness of problembased instruction: A comparative study of instructional methods and student characteristics. The Interdisciplinary Journal of Problem-based Learing, 1(2), 49-69. https://doi.org/10.7771/1541-5015.1026 .

Mutakinati, L., Anwari, I., \& Yoshisuke , K. (2018). Analysis Of Students' Critical Thinking Skill of Middle School Through STEM Education Project-based Learning . Jurnal Pendidikan IPA Indonesia JPII 7 (1) , 54-65.

Novella, S. (2012). Your Deceptive Mind: A Scientific Guide to Critical Thinking Skills. Course Guidebook. Chantilly: The Teaching Company.

OECD. (2005). School Factors Related To Quality And Equity. Results From PISA 2000. OECD.

Patton, A. (2012). Work that matters The teacher's guide to project-based learning. London: Paul Hamlyn Foundation.

Paul, R., \& Elder, L. (2004). The elements of critical thinking: Helping students assess their thinking: Defining. National Council for Excellence in Critical Thinking. Available from: http://www.criticalthinking.org/University/univclass/helps.html.

Penuel, W. R., \& Means, B. (2000). Designing a performance assessment to measure students' communication skills in multi-media-supported, project-based learning. New Orleans: Paper presented at the Annual Meeting of the American Educational Research Association.

Pereira, M. A., Barreto, M. A., \& Pazeti, M. (2017). Application of Project-Based Learning in the first year of an Industrial Engineering Program: lessons learned and challenges. . Production, 27(spe), 1-13. http://dx.doi.org/10.1590/01036513.223816 .

Peter, E. E. (2012). Critical thinking: Essence for teaching mathematics and mathematics problem solving skills. African Journal of Mathematics and Computer Science Research, 5(3), 39-43.

Pinho-Lopes, M., \& Macedo, J. (2014). Project-Based Learning to Promote High Order Thinking and Problem Solving Skills in Geotechnical Courses. iJEP, 4(5), 20-27. https://doi.org/10.3991/ijep.v4i5.3535. 
Reed, J. H., \& Kromrey, J. D. (2001). Teaching critical thinking in a community college history course: Emprical evidence from infusing Paul's model. College Student Journal, 35(2, 7-18.

Salas, E., SIms, D. E., \& Burke, C. S. (2005). Is there a "Big Five" in teamwork. Small Group Research 36(5), 555 - 599. https:// doi.org/10.1177/1046496405277134 .

Savin-Baden, M., \& Major, C. H. (2004). Foundations of Problem-Based Learning. Berkshire: Society for Research into Higher Education and Open University Press.

Sawamura, S. (2010). Assessment in project-based language learning. Hawaii Pacific University TESOL Working Paper Series 8, 44-49, http:/ / www.hpu.edu/index.cfm?contentID=8064\&siteID=1.

Schwalm, J., \& Tylek, K. S. (2012). Systemwide implementation of project-based learning the Philadelphia approach. Afterschool Matters Spring, 1 - 8.

Scriven, M., \& Paul, R. (2007). Defining critical thinking. The Critical Thinking Community: Foundation for Critical Thinking, http://www.criticalthinking.org/aboutCT/define_critical_thinking.cfm.

Smaldino, S. E. (2011). Preparing students with 21st century ICT literacy in math and science education. Journal of Curriculum and Instruction (JoCI), 5 (1), 1-3. https://doi.org/10.3776/joci.2011.v5n1p1-3 .

Soedijarto. (1997). Peranan Guru dalam Proses Peningkatan Kualitas Sumber Daya manusia Indonesia memasuki era pasar bebas abad XXI. In Soedijarto, Memanfaatkan kinerja sistem pendidikan nasional dalam menyiapkan manusia Indonesia memasuki abad ke-21 (pp. 81-93). ---: ---.

Solomon, G. (2003). Project-based learning: A primer. Technologyand learning, 23 (6), 2026.

Stancato, F. A. (2000). Tenure, academic freedom, and the teaching of critical thinking. College Student Journal, 34(3), 377-383.

Stepien, W. J., Gallagher, S. A., \& Workman, D. (1993). Problem-based learning for traditional and interdisciplinary classrooms. Journal for the Education of the Gifted, 16, 338-357. https://doi.org/10.1177/016235329301600402 .

Suyanto. (2013, Februari 15). Kurikulum pendidikan haruslah memberi tantangan bagi siswa. Kompas, p. 7.

Thomas, J. W. (2000). A A review of research on project-based learning. Report prepared for The Autodesk Foundation. Retrieved Januari 18, 2013 from http://www.bie.org/index.php/site/RE/pbl_research/29.

Uysal, F. (2015). Evaluation Of The Factors That Determine Quality In Graduate Education: Application Of A Satisfaction Benchmarking Approach. Procedia Social and Behavioral Sciences 191, 1034 - 1037. https://doi.org/10.1016/j.sbspro.2015.04.386 .

Volkov, A., \& Volkov, M. (2007). Teamwork and Assessment: a critique. E-Journal of Business Education \& Scholarship of Teaching Volume 1, Issue 1, 59-64.

Wong, D. (2007). Beyond control and rationality: Dewey, aesthetics, motivation. Teachers College Record, 109(1), 192-220.

Yildirim, B., \& Özkahraman, Ş. (2011). Critical Thinking in Nursing Process and Education. International Journal of Humanities and Social Science Vol. 1 No. 13 [Special Issue, 256 - 262. 